\title{
Valorization of Waste Lignocellulose to Furfural by Sulfonated Biobased Heterogeneous Catalyst Using Ultrasonic-Treated Chestnut Shell Waste as Carrier
}

\author{
Jianguang Liang ${ }^{1,+}$, Jingjian Zha ${ }^{1,+}$, Nana Zhao ${ }^{1}$, Zhengyu Tang ${ }^{1}$, Yucai He ${ }^{1,2, *(D)}$ and Cuiluan Ma ${ }^{2, *}$ \\ 1 National-Local Joint Engineering Research Center of Biomass Refining and High-Quality Utilization, \\ School of Pharmacy, Changzhou University, Changzhou 213164, China; liangig@cczu.edu.cn (J.L.); \\ 19081703859@smail.cczu.edu.cn (J.Z.); 19439113@smail.cczu.edu.cn (N.Z.); 18435417@smail.cczu.edu.cn (Z.T.) \\ 2 State Key Laboratory of Biocatalysis and Enzyme Engineering, School of Life Sciences, Hubei University, \\ Wuhan 430062, China \\ * Correspondence: yucaihe@cczu.edu.cn or heyucai2001@163.com (Y.H.); macuiluan@163.com (C.M.) \\ + Jianguang Liang and Jingiian Zha contributed equally to this work.
}

Citation: Liang, J.; Zha, J.; Zhao, N.; Tang, Z.; He, Y.; Ma, C. Valorization of Waste Lignocellulose to Furfural by Sulfonated Biobased Heterogeneous Catalyst Using Ultrasonic-Treated Chestnut Shell Waste as Carrier. Processes 2021, 9, 2269. https://doi. org/10.3390/pr9122269

Academic Editor: Alok Patel

Received: 28 November 2021 Accepted: 15 December 2021 Published: 17 December 2021

Publisher's Note: MDPI stays neutral with regard to jurisdictional claims in published maps and institutional affiliations.

Copyright: (c) 2021 by the authors. Licensee MDPI, Basel, Switzerland. This article is an open access article distributed under the terms and conditions of the Creative Commons Attribution (CC BY) license (https:// creativecommons.org/licenses/by/ $4.0 /)$.

\begin{abstract}
Recently, the highly efficient production of value-added biobased chemicals from available, inexpensive, and renewable biomass has gained more and more attention in a sustainable catalytic process. Furfural is a versatile biobased chemical, which has been widely used for making solvents, lubricants, inks, adhesives, antacids, polymers, plastics, fuels, fragrances, flavors, fungicides, fertilizers, nematicides, agrochemicals, and pharmaceuticals. In this work, ultrasonic-treated chestnut shell waste (UTS-CSW) was utilized as biobased support to prepare biomass-based heterogeneous catalyst (CSUTS-CSW) for transforming waste lignocellulosic materials into furfural. The pore and surface properties of CSUTS-CSW were characterized with BET, SEM, XRD, and FT-IR. In toluene-water (2:1, v:v; pH 1.0), CSUTS-CSW (3.6 wt $\%$ ) converted corncob into furfural yield in the yield of $68.7 \%$ at $180{ }^{\circ} \mathrm{C}$ in $15 \mathrm{~min}$. CSUTS-CSW had high activity and thermostability, which could be recycled and reused for seven batches. From first to seventh, the yields were obtained from 68.7 to $47.5 \%$. Clearly, this biobased solid acid CSUTS-CSW could be used for the sustainable conversion of waste biomasses into furfural, which had potential application in future.
\end{abstract}

Keywords: furfural; heterogeneous catalyst; chestnut shell; ultrasonic treatment; waste biomass

\section{Introduction}

Lignocellulosic biomass, mostly from agricultural and forestry solid waste, is expected to be a substitute considered a renewable resource for sustainable production of highvalue-added chemicals [1-3]. Furfural is among the important biobased chemicals, which can be transformed into various furan derivatives for making solvents, lubricants, inks, polymers, plastics, fragrances, antacids, fuels, adhesives, flavors, fungicides, fertilizers, nematicides, agrochemicals, and pharmaceuticals [4-11]. It can be valorized into various valuable intermediates, such as furfuryl alcohol, furfurylamine, furoic acid, succinic acid and $\gamma$-valerolactone [12-17]. It is also the precursor for the synthesis of biofuels, including valerate esters, pentanediol, and 2-methyltetrahydrofuran [18-20]. Typically, furfural is obtained through acid-catalyzed dehydration of xylose derived from hemicellulose in lignocellulosic biomass [21-23]. However, concentrated homogeneous inorganic acids can cause heavy reactor corrosion and serious environmental pollution [24]. Therefore, a clean and efficient catalytic system is required for furfural production in a sustainable and eco-friendly way.

Recently, the application of heterogeneous solid acid in furfural production has attracted more and more attention due to low corrosivity, good thermostability, and high catalytic activity. Numerous heterogeneous catalysts, including diatomite [25], glucosamine hydrochloride [26], sulfamic acid [27], resin [28], mesoporous tantalum phosphates [29], 
pectin [30], etc., have been discovered and utilized for furfural production. Very recently, biomass-based heterogeneous catalysts, including carbon, sucrose [31], miscanthus [32], and lignin [33], have gained considerable interest due to the utilization of available, inexpensive, and renewable biomass as a carrier. Carbon-based solid acid catalyst (SC-CCA) was synthesized by sulfonation of carbonaceous materials obtained by carbonization of sucrose with 4-BDS as a sulfonating agent. The yield of furfural was $60.6 \%$ at $200{ }^{\circ} \mathrm{C}$ in $100 \mathrm{~min}$. It is of great interest to develop biomass-based solid acid for sustainable catalysis of biomass into furfural in the high yields (over $65 \%$ ) below $200{ }^{\circ} \mathrm{C}$ in a relatively short reaction time.

Solvents have an important effect on the activity and selectivity for the formation of furfural [34]. The establishment of an organic solvent-water biphasic system might promote the furfural formation, facilitate the furfural separation, shift the reaction equilibrium, and reduce the formation of humins. Various organic solvents including 2methyltetrahydrofuran, methyl-isobutyl ketone, $\gamma$-butyrolactone, toluene, n-octane, and n-hexane have been used to construct effective reaction media for enhancing furfural synthesis [35]. Furfural was synthesized from corn straw with sulfonated carbon microspheres (C-Co-S) as a catalyst in $\gamma$-valerolactone-water $(17: 3, v: v)$ solvent. The furfural yield reached $59.5 \%$ at $170{ }^{\circ} \mathrm{C}$ in $3 \mathrm{~h} \mathrm{[27].} \mathrm{In} \gamma$-butyrolactone-water (1:1, v:v) at $210{ }^{\circ} \mathrm{C}$, Amberlyst-15 transformed alginic acid into furfural in the yield of $32 \%$ within $20 \mathrm{~min}$ [35]. In the presence of $\mathrm{AlCl}_{3}$ and $\mathrm{NaCl}$, furfural yield reached $55 \%$ from corn straw in tetrahydrofuran-water biphasic system under microwave at $160{ }^{\circ} \mathrm{C}$ in $1 \mathrm{~h} \mathrm{[36].} \mathrm{In} \mathrm{DMSO-toluene-water} \mathrm{(1:8:2,}$ v:v:v) containing $\mathrm{NaCl}(4 \% w / v), 2 \mathrm{wt} \%$ corn straw, and $10 \mathrm{wt} \% \mathrm{SO}_{4}{ }^{2-} / \mathrm{Sn}-\mathrm{TRP}$ catalyst (mass ratio and substrate), the yield of furfural reached $77.8 \%$ at $190{ }^{\circ} \mathrm{C}$ in $3 \mathrm{~h}$ [37]. In toluene-water (1:2. v:v), AAO@Al/FDU-5-7.5E-SO $\mathrm{S}_{3} \mathrm{H}$ catalyzed xylose to produce furfural in the yield of $66.2 \%$ at $160{ }^{\circ} \mathrm{C}$ in $4 \mathrm{~h}$ [38]. The solid lignin-based catalyst LC-1S was used to transform xylose into furfural in the yield of $65 \%$ at $175{ }^{\circ} \mathrm{C}$ within $3 \mathrm{~h}$ in methyl isobutyl ketone (MIBK) [39]. Clearly, a biomass-based solid acid catalyst could be prepared and utilized to convert waste biomass into furfural.

Chestnut shell waste (CSW) is one kind of available, abundant, and inexpensive agricultural waste [40]. Using ultrasonic-treated CSW as a carrier, tin-based solid acid catalyst CSUTS-CSW was prepared to transform biomass into furfural. The pore and surface properties of CSUTS-CSW were determined by X-ray diffraction (XRD), Scanning Electron Microscopy (SEM), Fourier transform infrared spectroscopy (FT-IR), and BrunauerEmmett-Teller (BET). To efficiently transform biomass into furfural, several parameters, including organic solvent type, organic solvent loading, catalyst CSUTS-CSW dosage, performance temperature, and reaction time, were used to examine the catalytic efficiency of CSUTS-CSW. The catalytic potency of CSUTS-CSW was explored using different biomasses as feedstocks under the optimized catalytic reaction system. In this study, the conversion of waste lignocellulose into furfural using the sulfonated biomass-based solid acid catalyst CSUTS-CSW was developed in an organic solvent-water system.

\section{Materials and Methods}

\subsection{Materials and Reagents}

Corncob (CC), corn stover (CS), sugarcane bagasse (SCB), and chestnut shell waste (CSW) were collected on local farms in LuAn City and Liuzhou (China). Toluene, $\mathrm{SnCl}_{4} \cdot 5 \mathrm{H}_{2} \mathrm{O}$, furfural (FAL), $\mathrm{NaOH}$, n-hexane, n-octane, methyl isobutyl ketone (MIBK), dimethyl sulfoxide (DMSO), $\gamma$-valerolactone (GVL), tetrahydrofuran (THF), dibutyl phthalate (DBP), and other chemicals were bought from Changzhou Runyou Reagent Co., (Changzhou, Jiangsu, China).

\subsection{Preparation of Solid Acid CSUTS-CSW}

Dried CSW powders $(500 \mathrm{~g})$ were mixed in $5 \mathrm{~L}$ of ethanol-acetone $(2: 1, v: v)$ for $6 \mathrm{~h}$. The solvent-extracted CSW (SE-CSW) samples were washed with deionized water and further dried in an oven $\left(60^{\circ} \mathrm{C}\right)$ (BGZ-70, Shanghai Boxun Medical Biological Instrument 
Co., Shanghai, China) for $15 \mathrm{~h}$. SE-CSW (100.0 g) was soaked in $1000 \mathrm{~mL} \mathrm{NaOH}(250 \mathrm{mM})$ in a sonicator (SB-5200DTS, Ningbo Scientz Biotechnology Co., Ltd., Ningbo, Zhejiang, China) $\left(300 \mathrm{~W}, 60^{\circ} \mathrm{C}\right)$ in $4 \mathrm{~h}$. The ultrasonic-treated SE-CSW (UTS-CSW) was isolated by filtration and further washed to neutrality with deionized water. UTS-CSW was immersed into $\mathrm{H}_{2} \mathrm{SO}_{4}(4.0 \mathrm{M}, 500 \mathrm{~mL})$ at $60^{\circ} \mathrm{C}$ for $4 \mathrm{~h}$ under the agitation $(300 \mathrm{rpm})$. The sulfonated UTS-CSW (SUTS-CSW) was filtrated and further oven-dried at $90^{\circ} \mathrm{C}$ in $12 \mathrm{~h}$. Dried SUTSCSW powder $(42 \mathrm{~g})$, ethanol $(500 \mathrm{~mL})$ and $\mathrm{SnCl}_{4} \cdot 5 \mathrm{H}_{2} \mathrm{O}(20 \mathrm{~g})$ were blended in $4 \mathrm{~h}$ at room temperature under the agitation (300 rpm). The formed mixture was oven-dried at $70{ }^{\circ} \mathrm{C}$ in $12 \mathrm{~h}$, and the obtained dry powder was further baked at $90^{\circ} \mathrm{C}$ in $12 \mathrm{~h}$. The baked powder was calcined at a high temperature $\left(550^{\circ} \mathrm{C}\right)$ using a muffle furnace (SX2-10-13A, Shanghai Leiyun Experimental Instrument Manufacturing Co., Ltd., (Shanghai, China) in $4 \mathrm{~h}$, and the calcined CSUTS-CSW was used as a solid acid catalyst for converting biomass into furfural.

\subsection{CSUTS-CSW Conversion of Biomass to Furfural in Toluene-Water}

Three grams of dry corncob powder (37.4\% glucan, $31.4 \%$ xylan, and $16.8 \%$ lignin) was mixed with CSUTS-CSW (0.6-6.0 $\mathrm{wt} \%$ ) at $160-180{ }^{\circ} \mathrm{C}$ for 5-60 $\mathrm{min}$ in an autoclave reactor (Zhenjiang Jingkou Dantu Electronic Equipment Co., (Zhenjiang, China) containing $40 \mathrm{~mL}$ organic solvent-water (0:1-4:1, v:v; $\mathrm{pH} 1.0)$. Furfural was measured by HPLC.

To examine the catalytic efficiency of CSUTS-CSW, furfural production from different biomasses was attempted. Biomass $(75.0 \mathrm{~g} / \mathrm{L})$ with CSUTS-CSW $(3.6 \mathrm{wt} \%)$ was incubated at $180^{\circ} \mathrm{C}$ for $15 \mathrm{~min}$ in toluene-water (2:1, v:v; pH 1.0). Furfural was analyzed with HPLC.

\subsection{Analytical Methods}

Monosugars (e.g., Glucose, $D$-xylose, and arabinose) and furfural were measured by HPLC (Model 2695, Waters Corporation, Milford, MA, USA) equipped with an Aminex HPX-87H column (Bio-Rad Laboratories, Hercules, CA, USA) at $65^{\circ} \mathrm{C}$, which were eluted with $5.0 \mathrm{mM} \mathrm{H}_{2} \mathrm{SO}_{4}$ at a flow rate of $0.60 \mathrm{~mL} / \mathrm{min}$ [24]. Furfural was determined by HPLC (Model 2695, Waters Corporation, Milford, MA, USA) equipped with reverse-phase C18 (Discovery C18, $3.9 \mathrm{~mm} \times 150 \mathrm{~mm}, 4 \mu \mathrm{m}$ ), which was eluted by $0.4 \%\left(\mathrm{NH}_{4}\right)_{2} \mathrm{SO}_{4} / \mathrm{CH}_{3} \mathrm{OH}$ $(95: 5, v: v)$ at a flow rate of $0.60 \mathrm{~mL} / \mathrm{min}$ at $254 \mathrm{~nm}$.

The yield of furfural was calculated according to the following equation:

$$
\text { Furfural yield }(\%)=\frac{\text { Furfural produced }(\mathrm{g}) \times 0.88}{\text { Biomass }(\mathrm{g}) \times \text { Xylan } \operatorname{content}(\%)} \times \frac{150}{96} \times 100 \%
$$

Carrier CSW and solid acid CSUTS-CSW were captured with JSM-6360LA Scanning Electron Microscopy (SEM) (JEOL, Tokyo, Japan) at 15 kV, Nikon Eclipse Ti-S Fluorescent Microscope (FM) at 100× NICOLET PROTÉGÉ 460 Fourier transformed IR (FTIR) spectra (Thermo Electron Co., Waltham, MA, USA) in the range between 4000 and $500 \mathrm{~cm}^{-1}$, and $\mathrm{D} / \mathrm{max} 2500 \mathrm{PC}$ X-ray diffraction (XRD) (Rigaku Co., Akishima-shi, Japan) in the $2 \theta$ range between $5^{\circ}$ and $80^{\circ}$ in steps of $0.02^{\circ}$ [41,42]. The Brunauer-Emmett-Teller (BET) method was applied to calculate the specific surface area on the basis of $\mathrm{N}_{2}$ adsorption isotherm measurements at $77 \mathrm{~K}$, and Barrett-Joyner-Halenda (BJH) was used to determine the pore size distribution based on the $\mathrm{N}_{2}$ desorption isotherm measurements, and the pore volume was determined on the basis of $\mathrm{N}_{2}$ adsorption at $p / p_{o}=0.98$. The chemical compositions of biomass were determined as reported National Renewable Energy Laboratory (NREL) procedure in reference [43].

\section{Results and Discussion}

\subsection{Characterization of CSUTS-CSW}

Various processes have been used to prepare solid acid catalysts. As a process enhancement technology, ultrasonic is considered to be an effective means. It might clean the solid particle surface in fluid (solvent) by generating impact (e.g., cavity effect), which leads to the rupture or collapse of solid powders under the instantaneous high-pressure 
and medium temperature [44]. In addition, ultrasonic has been applied to increase biomass porosity $[45,46]$. Under the ultrasonic-assisted modification, the crystallinity of zeolite decreased, which resulted in an enlarged pore [44,47]. In this study, CSW and ultrasonictreated CSW (US-CSW) were used as biobased supports for the preparation of sulfonated tin-based heterogeneous catalyst CSUTS-CSW. These catalysts were determined with SEM, FT-IR, XRD, and BET.

SEM was used to characterize the surface property of CSW and CSUTS-CSW (Figure 1). The fresh CSW surface was smooth, while the CSUTS-CSW surface was relatively rough. Different particle size distribution was observed on CSW and CSUTS-CSW. The rough structure of CSUTS-CSW might promote the formation of covalent bonds between the carbon groups and $\mathrm{SnO}_{2}$. FT-IR, which could be observed in the wavenumber range 600-3600 $\mathrm{cm}^{-1}$, was used for the determination of fresh CSW and CSUTS-CSW (Figure 2A). The peaks near 1601 and $3395 \mathrm{~cm}^{-1}$ were associated with $-\mathrm{OH}$. The peak near $2924 \mathrm{~cm}^{-1}$ was related to the stretching of $\mathrm{C}-\mathrm{H}$. The peak near $1034 \mathrm{~cm}^{-1}$ was ascribed to the stretching of $\mathrm{S}=\mathrm{O}$, indicating the existence of $-\mathrm{SO}_{3} \mathrm{H}$ [37]. The peak near $770 \mathrm{~cm}^{-1}$ was attributed to the bending of $\mathrm{Si}-\mathrm{O}-\mathrm{Si}$ [48]. The peak near $664 \mathrm{~cm}^{-1}$ was related to $\mathrm{SnO}_{2}$. XRD was employed to measure the crystallinity of CSW and CSUTS-CSW (Figure 2B). The angles of $26.5^{\circ}, 33.8^{\circ}$, and $51.7^{\circ}$ might be ascribed to the tetrahedral type of $\mathrm{SnO}_{2}$ [37]. Ultrasonic treatment and $\mathrm{NaOH}(1 \mathrm{wt} \%)$ soaking might form the exposed surfaces, remove amorphous components and make biomass loose [49], which resulted in the increased crystallinity index ( $\mathrm{CrI}$ ) of CSUTS-CSW. The surface and pore properties of CSUTS-CSW and Sn-CSW were also determined via the BET method (Table 1). Compared to fresh CSW (Specific surface area (SSA): $0.2 \mathrm{~m}^{2} / \mathrm{g}$; pore volume: $<0.01 \mathrm{~cm}^{3} / \mathrm{g}$; pore diameter: $\left.13.6 \mathrm{~nm}\right)$, CSUTSCSW had increased SSA $\left(321.5 \mathrm{~m}^{2} / \mathrm{g}\right)$, enlarged pore volume $\left(0.2 \mathrm{~cm}^{3} / \mathrm{g}\right)$ and reduced pore diameter $(2.7 \mathrm{~nm})$. In the preparation of CSUTS-CSW, carrier CSW was treated with ethanol-acetone, $\mathrm{NaOH}$, ammonia, and $\mathrm{H}_{2} \mathrm{SO}_{4}$. The formed porous structure and the rough surface might result in structural defects and more catalytic active sites on the solid acid catalysts.

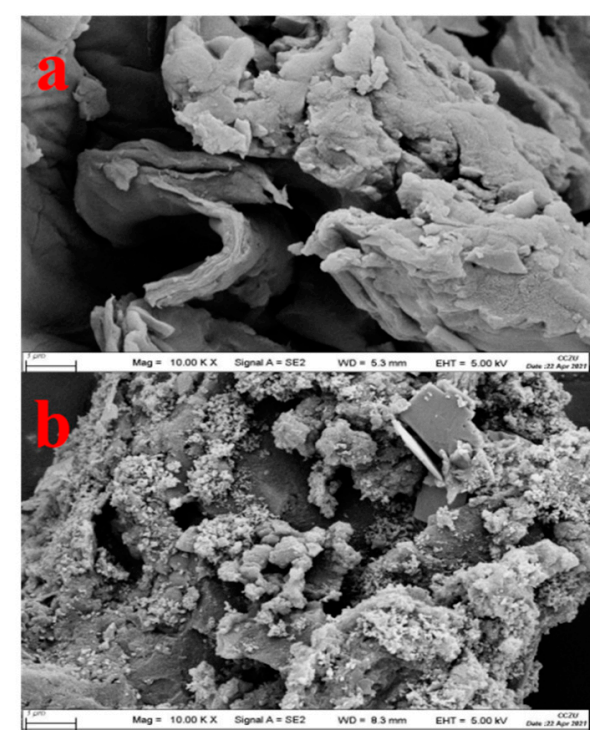

Figure 1. SEM image of CSW (a) and CSUTS-CSW (b). 

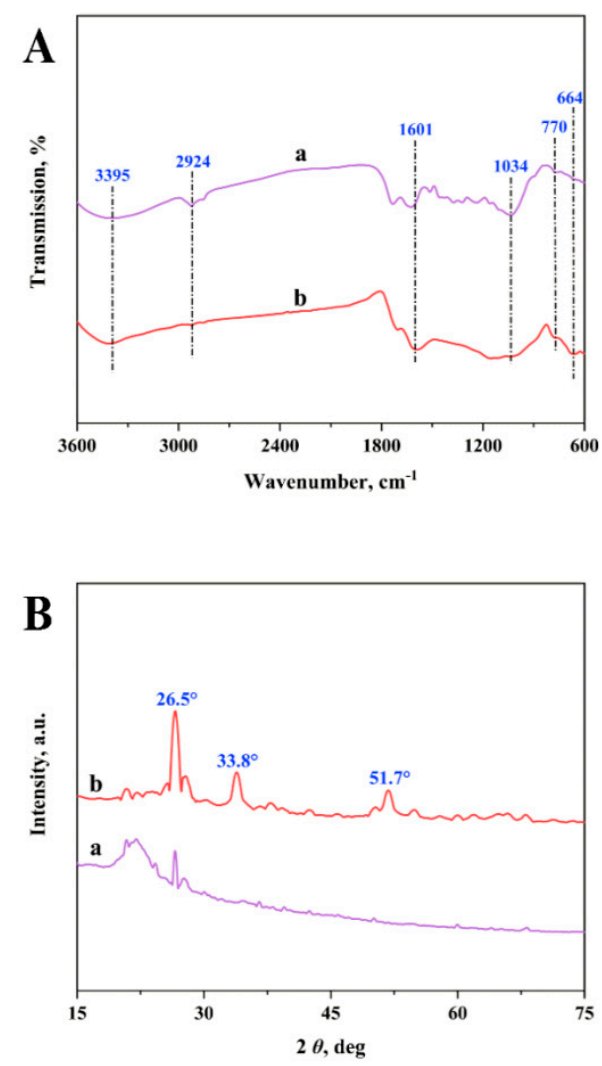

Figure 2. FT-IR (A) and XRD (B) analysis of CSW (a) and CSUTS-CSW (b).

Table 1. Characterization of CSW and CSUTS-CSW ${ }^{\mathrm{a}}$.

\begin{tabular}{cccc}
\hline CSW Samples & $\mathbf{S S A}, \mathbf{~}^{\mathbf{2}} \mathbf{g}$ & Pore Volume, $\mathbf{c m}^{\mathbf{3}} \mathbf{g}$ & Pore Diameter, $\mathbf{n m}$ \\
\hline CSW & 0.2 & $<0.01$ & 13.6 \\
CSUTS-CSW & 321.5 & 0.20 & 2.7 \\
\hline
\end{tabular}

a BET method was applied to calculate the SSA on the basis of $\mathrm{N}_{2}$ adsorption isotherm measurements at $77 \mathrm{~K}$ and $\mathrm{BJH}$ was used to determine the pore size distribution based on the $\mathrm{N}_{2}$ desorption isotherm measurements, and the pore volume was determined on the basis of $\mathrm{N}_{2}$ adsorption at $p / p_{0}=0.98$.

\subsection{Optimization of Reaction Conditions in Organic Solvent-Water}

To prevent the furfural's rapid degradation to chars and humins under high reaction temperature [24], various organic solvents, including n-hexane, n-octane, methyl isobutyl ketone (MIBK), dimethyl sulfoxide (DMSO), $\gamma$-valerolactone (GVL), tetrahydrofuran (THF), and dibutyl phthalate (DBP), were individually mixed with water to form catalytic reaction media ( $\mathrm{pH}$ 1.0) for enhancing furfural production. Using CSUTS-CSW as catalyst in organic solvent-water $(1: 1, v: v)$ at $180^{\circ} \mathrm{C}$ in $15 \mathrm{~min}$ (Figure 3a), the furfural yields were obtained as follows: $\left.Y_{(\text {toluene) }}=60.5 \%>Y_{(\text {MIBK })}=52.4 \%>Y_{(\text {n-hexane })}=49.9 \%>Y_{(\mathrm{DBP})}=48.8 \%>Y_{(\mathrm{THF}}\right)$ $=48.5 \%>Y_{(\mathrm{GVL})}=47.2 \%>Y_{(\text {n-octane })}=46.7 \%>Y_{(\mathrm{DMSO})}=44.8 \%>\mathrm{Y}_{(\text {water })}=44.5 \%$. Toluene could significantly enhance the yield of furfural, and the furfural yield reached $60.5 \%$ in toluene-water $(1: 1, v: v)$. Furthermore, the effects of toluene dosage on the furfural yield were evaluated in toluene-water (Figure $3 b$ ). By raising the toluene-to-water volumetric ratio from $1: 4$ to $2: 1$, furfural yields increased from $54.1 \%$ to $68.7 \%$ at $180{ }^{\circ} \mathrm{C}$ in $15 \mathrm{~min}$. Further increasing this ratio from 2:1 to $4: 1$ (v:v), the yields of furfural slightly increased from $68.7 \%$ to $71.8 \%$. To reduce the toluene dosage, the appropriate reaction medium was chosen as toluene-water $(2: 1, v: v)$. 

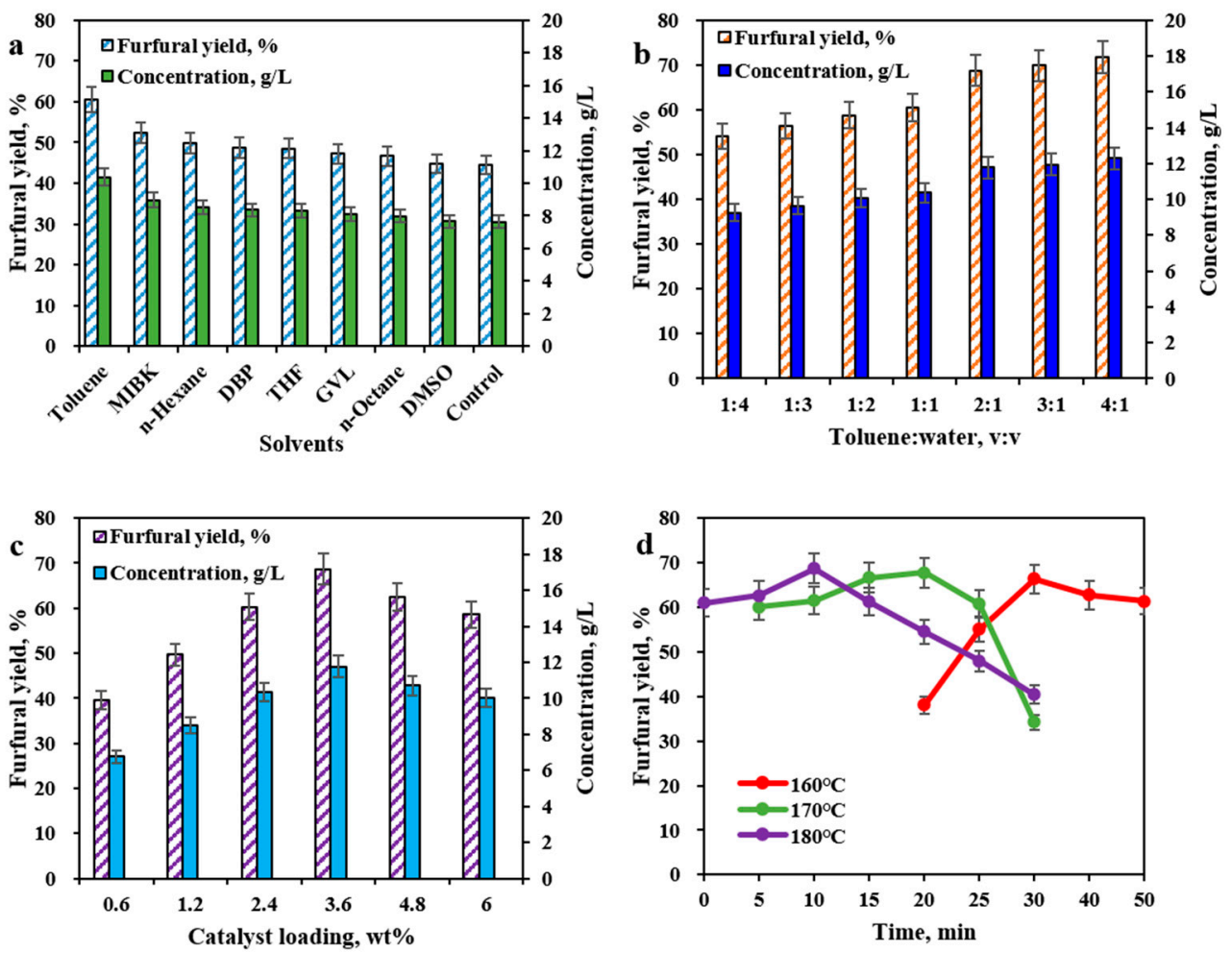

Figure 3. Effects of organic solvent types on the furfural yields in organic solvent-water $(1: 1, v: v)$ (75 g/L CC, $180{ }^{\circ} \mathrm{C}, 15 \mathrm{~min}$ ) (a); Effects of the toluene-to-water ratio on the furfural yields (1:4-4:1, v:v) (75 g/L CC, $\left.180{ }^{\circ} \mathrm{C}, 15 \mathrm{~min}\right)(\mathbf{b})$; Effects of catalyst CSUTS-CSW loading (0.6-6 wt\%) on the furfural yields in toluene-water $(2: 1, v: v)\left(75 \mathrm{~g} / \mathrm{L} \mathrm{CC}, 180^{\circ} \mathrm{C}, 15 \mathrm{~min}\right)(\mathrm{c})$; Effects of temperature $\left(160-180^{\circ} \mathrm{C}\right)$ and time (5-60 min) on the furfural yields in toluene-water (2:1, v:v) (75 g/L CC, $3.6 \mathrm{wt} \%$ CSUTS-CSW) (d). ( \pm Standard error $(n=6), p \leq 0.05)$.

Solid acid catalyst dosage might have significant influences on the production of furfural [50]. In toluene-water (2:1, v:v; $\mathrm{pH} 1.0)$, different dose of CSUTS-CSW (0.6-6.0 wt \%) were examined on the effects of furfural formation (Figure 3c). When CSUTS-CSW dosage was rose from $0.6 \%$ to $3.6 \%$, the yields of furfural were raised from $39.5 \%$ to $68.7 \%$. Upon raising CSUTS-CSW loading from 3.6 to $6.0 \mathrm{wt} \%$, furfural yields decreased. Excessive acidity might cause unwanted side reactions and reduce furfural yields. In toluene-water $(2: 1, v: v)$, highest furfural yield reached $68.7 \%$ from CC $(75.0 \mathrm{~g} / \mathrm{L})(37.4 \%$ glucan, $31.4 \%$ xylan, and $16.8 \%$ lignin) with $3.6 \mathrm{wt} \%$ of CSUTS-CSW. Performance temperature and reaction time have profound effects on furfural generation [42]. In toluene-water (2:1, v:v), CC (75.0 g/L) was catalyzed into furfural using CSUTS-CSW (3.6 wt $\%)$ as catalyst at $160-180^{\circ} \mathrm{C}$ in 5-60 min (Figure $3 \mathrm{~d}$ ). Higher performance temperature facilitates the furfural generation at $160-180^{\circ} \mathrm{C}$. At 160,170 , and $180{ }^{\circ} \mathrm{C}$, the highest furfural yields were obtained as follows: Yield $_{\left(180^{\circ} \mathrm{C}\right)}=68.7 \%(15 \mathrm{~min})>\operatorname{Yield}_{\left(170^{\circ} \mathrm{C}\right)}=67.7 \%(25 \mathrm{~min})>$ Yield $_{\left(160^{\circ} \mathrm{C}\right)}=66.3 \%(40 \mathrm{~min})$. Clearly, the optimum performance temperature and reaction time were $180{ }^{\circ} \mathrm{C}$ and $15 \mathrm{~min}$, respectively. In furfural liquor, the glucose, xylose, and arabinose content were 1.6, 0.9 , and $1.3 \mathrm{~g} / \mathrm{L}$, respectively. The $\mathrm{CC}$ residue was composed of $69.8 \%$ glucan, $4.9 \%$ xylan and $8.5 \%$ lignin. At $170{ }^{\circ} \mathrm{C}$, sulfonated montmorillonite (MMT) converted $D$-xylose to furfural in the yield of $48.3 \%$ within $20 \mathrm{~min}$ in toluene-water [24]. To explore the catalytic ability of CSUTS-CSW, corncob (CC), corn stover (CS), and sugarcane bagasse (SCB) $(75.0 \mathrm{~g} / \mathrm{L})$ were used as feedstocks for the production of furfural at $180^{\circ} \mathrm{C}$ for $15 \mathrm{~min}$ in toluene-water (2:1, v:v; $\mathrm{pH} 1.0)$. The furfural yields were obtained as follows: Yield $_{(\mathrm{CC})}=68.7 \%>$ Yield $_{(\mathrm{CS})}=61.2 \%>$ Yield $_{(\mathrm{SCB})}=42.1 \%$. Significantly, biomass-based heterogeneous catalyst CSUTS-CSW had high catalytic activity for converting biomass to furfural. 


\subsection{Reuse of CSUTS-CSW}

To evaluate the durability of the CSUTS-CSW, the recycling tests of CSUTS-CSW were performed for the furfural production from CC. After each run, the catalysts were separated by filtration and washed with deionized water and ethanol repeatedly, then heated at $80^{\circ} \mathrm{C}$ for $12 \mathrm{~h}$. After that, the dried solid acid powder is calcined in a muffle furnace $\left(550{ }^{\circ} \mathrm{C}, 4 \mathrm{~h}\right)$ Figure 4 showed the yield and selectivity of furfural after each reaction run. The gradual decrease of $68.7-47.5 \%$ in the yield was probably attributed to the loss of acid groups and catalyst mass. $\mathrm{SO}_{4}{ }^{2-} / \mathrm{SnO}_{2}$-DM could be reused for five runs, and furfural yield decreased from $69 \%$ to $58 \%$ [48]. $\mathrm{Cl}_{0.3}-\mathrm{S}-\mathrm{R}$ was reused for five runs of corn stover dehydration in $15 \mathrm{~mL}$ 1,4-dioxane and $1.5 \mathrm{~mL}$ water, and the furfural yield dropped from $54.2 \%$ to $18.7 \%$ at $190{ }^{\circ} \mathrm{C}$ for $80 \mathrm{~min}$ [51].

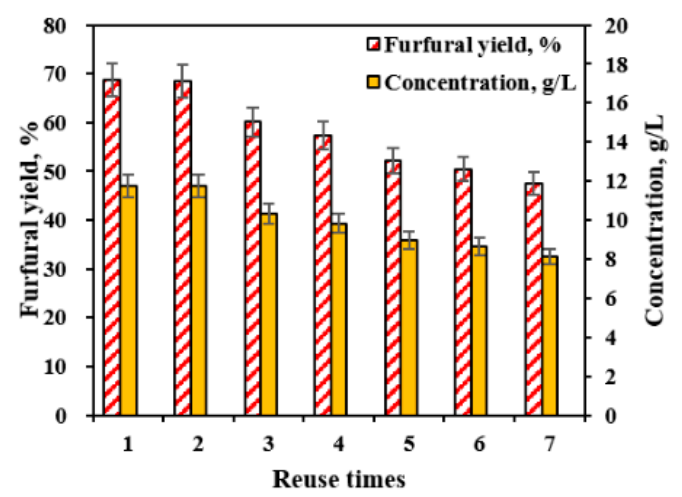

Figure 4. Reuse of CSUTS-CSW in toluene-water (2:1, v:v) (75 g/L CC, $3.6 \mathrm{wt} \%$ CSUTS-CSW, NaCl $\left.(200 \mathrm{mM}), 180^{\circ} \mathrm{C}, 15 \mathrm{~min}\right)( \pm$ Standard error $(n=6), p \leq 0.05)$.

\subsection{Catalysis of Biomass to Furfural with CSUTS-CSW in Toluene-Water}

Alkali treatment of biomass can effectively remove lignin, which would improve the content of cellulose and hemicellulose in biomass [52]. In addition, various biomass components are complex and contain impurities, such as oil and pigment. $\mathrm{NaOH}(1 \mathrm{wt} \%)$ was used for biomass pretreatment to reduce the impact of impurities on furfural production.

In toluene-water, CSUTS-CSW catalyst might be facilitated to pretreat biomass, hydrolyze biomass, and dehydrate biomass-derived C6 and C5 sugars, which would result in the generation of furan chemicals and soluble sugars. A possible mechanism involving CSUTS-CSW-catalyzed biomass to furfural was proposed in toluene-water (Figure 5). The formed furfural might be immediately extracted with toluene, which would inhibit potential side reactions, promote furfural formation, and enhance furfural productivity [42] The acidity of CSUTS-CSW could create an acidic environment, which might result in the dissolution of hemicellulose, hydrolysis of hemicellulose, and dehydration of hemicellulosevalorized $D$-xylose to furfural. The production of furfural was performed via aldose-ketose isomerization of $D$-xylose to xylulose and successive dehydration of xylulose to furfural by CSUTS-CSW. Under acidic conditions, glucan could be hydrolyzed into $D$-glucose, which might be isomerized to $D$-fructose and further dehydrated into 5-HMF. This formed 5-HMF would easily react with water to form levulinic acid and formic acid. In toluene- $\mathrm{H}_{2} \mathrm{O}$, waste biomass was effectively valorized into furfural and its derivatives with the biobased CSUTS-CSW catalyst using ultrasonic-treated CSW as a biomass-based carrier. In future, it would be of great interest to establish a highly efficient valorization process for sustainable production of furfural with high productivity in benign reaction media. 


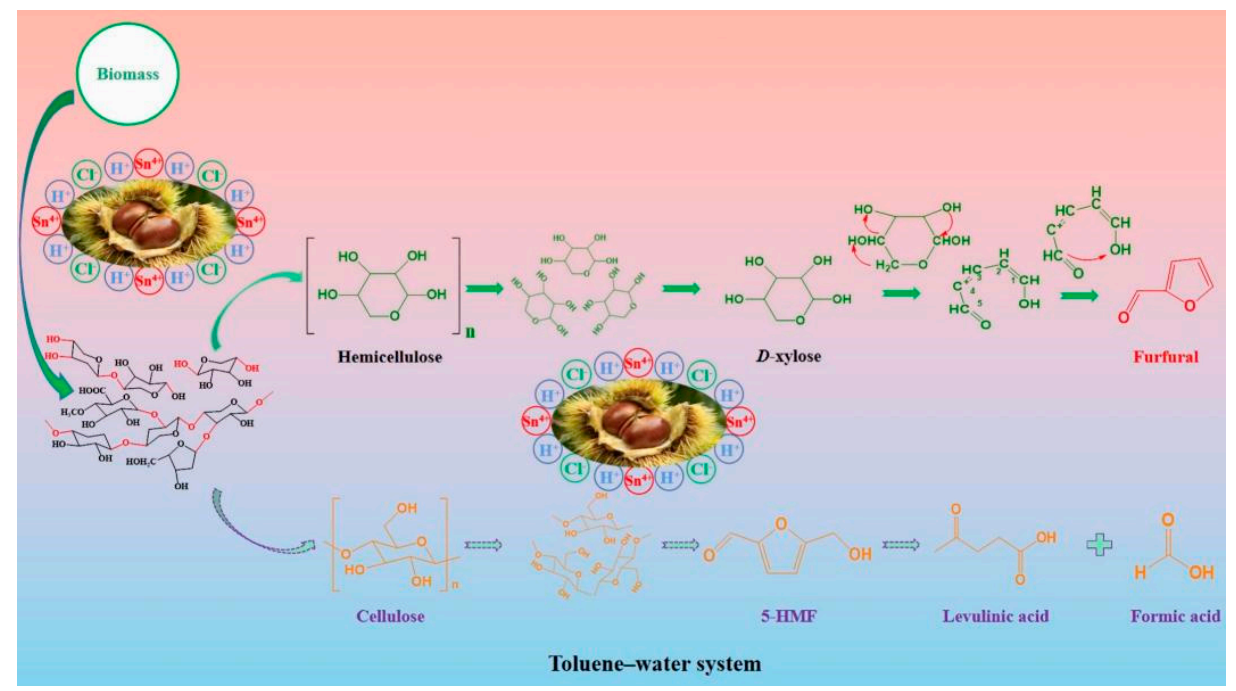

Figure 5. Possible mechanism involving CSUTS-CSW-catalyzed biomass to furfural in toluene-water.

\section{Conclusions}

It is of great interest to establish a highly efficient strategy for the conversion of available, inexpensive, and renewable biomass into value-added furfural in a sustainable catalytic process. Using available CSW as a biomass-based carrier, a novel heterogeneous catalyst CSUTS-CSW was prepared via ultrasonic treatment, which could be used to transform raw CC into furfural in the yield of $68.7 \%$ at $180{ }^{\circ} \mathrm{C}$ within $15 \mathrm{~min}$ in toluenewater (2:1, v:v; $\mathrm{pH} 1.0)$. CSUTS-CSW could be recycled for seven batches, and the furfural yields were obtained from $68.7 \%$ to $47.5 \%$. In this study, a sustainable strategy for the utilization of biobased CSUTS-CSW to catalyze waste biomasses into furfural in an organic solvent-water biphasic system. From the view of industrial technology applications, it has gained great interest to establish a cost-effective catalytic process for enhancing the production of FAL from lignocellulose biomass using biomass-based heterogeneous catalyst in an environmentally friendly reaction system. In addition, phenolic compounds derived from lignin and glucose derived from cellulose in biomass slurry can be further valorized into value-added chemicals and biofuels. Using the abundant and renewable biomass as feedstocks, this developed one-pot catalytic strategy has potential application in future.

Author Contributions: Conceptualization, methodology, and writing original draft, J.L. and J.Z.; data curation, N.Z.; software, Z.T.; supervision, review and revising manuscript, Y.H. and C.M. All authors have read and agreed to the published version of the manuscript.

Funding: The authors gratefully acknowledge the Postgraduate Research and Practical Innovation Program of Jiangsu Province (KYCX21-2867; SJCX21-1244; SJCX21-1245; SJCX21-1246).

Institutional Review Board Statement: Not applicable.

Informed Consent Statement: Not applicable.

Data Availability Statement: Not applicable.

Conflicts of Interest: The authors declare no conflict of interest.

\section{References}

1. Filiciotto, L.; Balu, A.M.; Van der Waal, J.C.; Luque, R. Catalytic insights into the production of biomass-derived side products methyl levulinate, furfural and humins. Catal. Today 2017, 302, 2-15. [CrossRef]

2. $\mathrm{Xu}, \mathrm{J} . ; \mathrm{Gao}, \mathrm{Z} . ; \mathrm{Wu}, \mathrm{B}$; He, B. Lactose-inducted production of a complete lignocellulolytic enzyme system by a novel bacterium Bacillus sp. BS-5 and its application for saccharification of alkali-pretreated corn cob. Cellulose 2017, 24, 2059-2070. [CrossRef]

3. Yan, Y.; Bu, C.; He, Q.; Zheng, Z.; Ouyang, J. Efficient bioconversion of furfural to furfuryl alcohol by Bacillus coagulans NL01. RSC Adv. 2018, 8, 26720-26727. [CrossRef] 
4. Chen, S.-H.; Tseng, Y.-C.; Yang, S.-C.; Lin, S.D. Investigating hydrogenation and decarbonylation in vapor-phase furfural hydrotreating over $\mathrm{Ni} / \mathrm{SiO}_{2}$ catalysts: Propylene production. Appl. Catal. A Gen. 2021, 613, 118020. [CrossRef]

5. Dessie, W.; Xin, F.; Zhang, W.; Zhou, J.; Wu, H.; Ma, J.; Jiang, M. Inhibitory effects of lignocellulose pretreatment degradation products (hydroxymethylfurfural and furfural) on succinic acid producing Actinobacillus succinogenes. Biochem. Eng. J. 2019, 150, 107263. [CrossRef]

6. Guimaraes, T.A.S.; da Cunha, J.N.; Oliveira, G.A.; Da Silva, T.U.; Oliveira, S.M.; Araujo, J.R.; Machado, S.D.; Elia, E.; Rezende, M.J.C. Nitrogenated derivatives of furfural as green corrosion inhibitors for mild steel in $\mathrm{HCl}$ solution. J. Mater. Res. Technol. 2020, 9, 7104-7122. [CrossRef]

7. Natsir, T.A.; Shimazu, S. Fuels and fuel additives from furfural derivatives via etherification and formation of methylfurans. Fuel Process. Technol. 2020, 200, 106308. [CrossRef]

8. Nemitz, M.C.; Teixeira, H.F.; Von Poser, G.L. A new approach for the purification of soybean acid extract: Simultaneous production of an isoflavone aglycone-rich fraction and a furfural derivative-rich by-product. Ind. Crops Prod. 2015, 67, 414-421. [CrossRef]

9. Tarazanov, S.; Grigoreva, K.; Shipitcyna, A.; Repina, O.; Ershov, M.; Kuznetsova, S.; Nikulshin, P. Assessment of the chemical stability of furfural derivatives and the mixtures as fuel components. Fuel 2020, 271, 117594. [CrossRef]

10. Techie-Menson, R.; Rono, C.K.; Etale, A.; Mehlana, G.; Darkwa, J.; Makhubela, B.C. New bio-based sustainable polymers and polymer composites based on methacrylate derivatives of furfural, solketal and lactic acid. Mater. Today Commun. 2021, $28,102721$. [CrossRef]

11. Zhang, J.; Liu, B.; Zhou, Y.; Essawy, H.; Chen, Q.; Zhou, X.; Du, G. Preparation of a starch-based adhesive cross-linked with furfural, furfuryl alcohol and epoxy resin. Int. J. Adhes. Adhes. 2021, 110, 102958. [CrossRef]

12. Li, Q.; Ma, C.-L.; Zhang, P.-Q.; Li, Y.-Y.; Zhu, X.; He, Y.-C. Effective conversion of sugarcane bagasse to furfural by coconut shell activated carbon-based solid acid for enhancing whole-cell biosynthesis of furfurylamine. Ind. Crops Prod. 2021, 160, 113169. [CrossRef]

13. Li, Y.-Y.; Li, Q.; Zhang, P.-Q.; Ma, C.-L.; Xu, J.-H.; He, Y.-C. Catalytic conversion of corncob to furfuryl alcohol in tandem reaction with tin-loaded sulfonated zeolite and NADPH-dependent reductase biocatalyst. Bioresour. Technol. 2021, 320, 124267. [CrossRef] [PubMed]

14. Papanikolaou, G.; Lanzafame, P.; Perathoner, S.; Centi, G.; Cozza, D.; Giorgianni, G.; Migliori, M.; Giordano, G. High performance of $\mathrm{Au} / \mathrm{ZTC}$ based catalysts for the selective oxidation of bio-derivative furfural to 2-furoic acid. Catal. Commun. 2021, $149,106234$. [CrossRef]

15. Shao, Y.W.; Li, Q.Y.; Dong, X.Y.; Wang, J.Z.; Sun, K.; Zhang, L.J.; Zhang, S.; Xu, L.L.; Yuan, X.Z.; Hu, X. Cooperation between hydrogenation and acidic sites in Cu-based catalyst for selective conversion of furfural to gamma-valerolactone. Fuel 2021, 293, 120457. [CrossRef]

16. Thubsuang, U.; Chotirut, S.; Nuithitikul, K.; Payaka, A.; Manmuanpom, N.; Chaisuwan, T.; Wongkasemjit, S. Oxidative upgrade of furfural to succinic acid using $\mathrm{SO}_{3} \mathrm{H}$-carbocatalysts with nitrogen functionalities based on polybenzoxazine. J. Colloid Interface Sci. 2020, 565, 96-109. [CrossRef]

17. Xue, X.-X.; Di, J.-H.; He, Y.-C.; Wang, B.-Q.; Ma, C.-L. Effective utilization of carbohydrate in corncob to synthesize furfuralcohol by chemical-enzymatic catalysis in toluene-water media. Appl. Biochem. Biotechnol. 2018, 185, 42-54. [CrossRef]

18. Golubeva, M.A.; Maximov, A.L. Selective production of $\gamma$-valerolactone and ethyl valerate from ethyl levulinate using unsupported nickel phosphide. Appl. Catal. A Gen. 2021, 628, 118401. [CrossRef]

19. Fu, X.; Ren, X.; Shen, J.; Jiang, Y.; Wang, Y.; Orooji, Y.; Xu, W.; Liang, J. Synergistic catalytic hydrogenation of furfural to 1,2-pentanediol and 1,5-pentanediol with LDO derived from CuMgAl hydrotalcite. Mol. Catal. 2021, 499, 111298. [CrossRef]

20. Gao, L.; Miletto, I.; Ivaldi, C.; Paul, G.; Marchese, L.; Coluccia, S.; Jiang, F.; Gianotti, E.; Pera-Titus, M. Rational design of bifunctional hierarchical Pd/SAPO-5 for the synthesis of tetrahydrofuran derivatives from furfural. J. Catal. 2021, 397, 75-89. [CrossRef]

21. Wang, X.; Liu, Y.; Cui, X.; Xiao, J.; Lin, G.; Chen, Y.; Yang, H.; Chen, H. Production of furfural and levoglucosan from typical agricultural wastes via pyrolysis coupled with hydrothermal conversion: Influence of temperature and raw materials. Waste Manag. 2020, 114, 43-52. [CrossRef] [PubMed]

22. Yin, Y.; Gao, Y.; Li, A. Self-activation of biochar from furfural residues by recycled pyrolysis gas. Waste Manag. 2018, 77, 312-321. [CrossRef]

23. Zhang, L.; Li, S.; Ding, H.; Zhu, X. Two-step pyrolysis of corncob for value-added chemicals and high-quality bio-oil: Effects of alkali and alkaline earth metals. Waste Manag. 2019, 87, 709-718. [CrossRef]

24. Qing, Q.; Guo, Q.; Zhou, L.; Wan, Y.; Xu, Y.; Ji, H.; Gao, X.; Zhang, Y. Catalytic conversion of corncob and corncob pretreatment hydrolysate to furfural in a biphasic system with addition of sodium chloride. Bioresour. Technol. 2017, 226, 247-254. [CrossRef]

25. Cai, D.; Chen, H.; Zhang, C.; Teng, X.; Li, X.; Si, Z.; Li, G.; Yang, S.; Wang, G.; Qin, P. Carbonized core-shell diatomite for efficient catalytic furfural production from corn cob. J. Clean. Prod. 2021, 283, 125410. [CrossRef]

26. Yang, T.; Li, W.Z.; Ogunbiyi, A.T.; An, S.X. Efficient catalytic conversion of corn stover to furfural and 5-hydromethylfurfural using glucosamine hydrochloride derived carbon solid acid in Upsilon-valerolactone. Ind. Crops Prod. 2020, 161, 113173. [CrossRef]

27. Zhang, Q.; Wang, C.; Mao, J.; Ramaswamy, S.; Zhang, X.; Xu, F. Insights on the efficiency of bifunctional solid organocatalysts in converting xylose and biomass into furfural in a GVL-water solvent. Ind. Crops Prod. 2019, 138, 111454. [CrossRef] 
28. Zhang, T.; Li, W.; An, S.; Huang, F.; Li, X.; Liu, J.; Pei, G.; Liu, Q. Efficient transformation of corn stover to furfural using p-hydroxybenzenesulfonic acid-for-maldehyde resin solid acid. Bioresour. Technol. 2018, 264, 261-267. [CrossRef]

29. Xing, Y.; Yan, B.; Yuan, Z.; Sun, K. Mesoporous tantalum phosphates: Preparation, acidity and catalytic performance for xylose dehydration to produce furfural. RSC Adv. 2016, 6, 59081-59090. [CrossRef]

30. Xu, H.; Xiong, S.; Zhao, Y.; Zhu, L.; Wang, S. Conversion of xylose to furfural catalyzed by carbon-based solid acid prepared from pectin. Energy Fuels 2021, 35, 9961-9969. [CrossRef]

31. Zhang, T.; Li, W.; Xu, Z.; Liu, Q.; Ma, Q.; Jameel, H.; Chang, H.-M.; Ma, L. Catalytic conversion of xylose and corn stalk into furfural over carbon solid acid catalyst in $\gamma$-valerolactone. Bioresour. Technol. 2016, 209, 108-114. [CrossRef]

32. Wang, Y.; Delbecq, F.; Kwapinski, W.; Len, C. Application of sulfonated carbon-based catalyst for the furfural production from d-xylose and xylan in a microwave-assisted biphasic reaction. Mol. Catal. 2017, 438, 167-172. [CrossRef]

33. Rusanen, A.; Kupila, R.; Lappalainen, K.; Kärkkäinen, J.; Hu, T.; Lassi, U. Conversion of xylose to furfural over lignin-based activated carbon-supported iron catalysts. Catalysts 2020, 10, 821. [CrossRef]

34. Bhaumik, P.; Dhepe, P.L. Exceptionally high yields of furfural from assorted raw biomass over solid acids. RSC Adv. 2014, 4, 26215-26221. [CrossRef]

35. Kim, H.; Yang, S.; Kim, D. One-pot conversion of alginic acid into furfural using Amberlyst-15 as a solid acid catalyst in gamma-butyrolactone/water co-solvent system. Environ. Res. 2020, 187, 109667. [CrossRef] [PubMed]

36. Yang, Y.; Hu, C.W.; Abu-Omar, M.M. Synthesis of furfural from xylose, xylan, and biomass using $\mathrm{AlCl}_{3}$ center dot $6 \mathrm{H}(2) \mathrm{O}$ in biphasic media via xylose isomerization to xylulose. ChemSusChem 2012, 5, 405-410. [CrossRef] [PubMed]

37. Teng, X.; Si, Z.; Li, S.; Yang, Y.; Wang, Z.; Li, G.; Zhao, J.; Cai, D.; Qin, P. Tin-loaded sulfonated rape pollen for efficient catalytic production of furfural from corn stover. Ind. Crops Prod. 2020, 151, 112481. [CrossRef]

38. Hu, S.J.; Zhu, J.H.; Wu, Y.L.; Xie, R.R.; Wu, K.J.; Yang, M.D. Preparation of packing type catalysts $\mathrm{AAO} @ \mathrm{Al} / \mathrm{Meso}^{-S i O}{ }_{2}-\mathrm{SO} 3 \mathrm{H}$ for the dehydration of xylose into furfural. Microporous Mesoporous Mater. 2018, 262, 112-121. [CrossRef]

39. Antonyraj, C.A.; Haridas, A. A lignin-derived sulphated carbon for acid catalyzed transformations of bio-derived sugars. Catal. Commun. 2018, 104, 101-105. [CrossRef]

40. Costa-Trigo, I.; Otero-Penedo, P.; Outeiriño, D.; Paz, A.; Domínguez, J.M. Valorization of chestnut (Castanea sativa) residues: Characterization of different materials and optimization of the acid-hydrolysis of chestnut burrs for the elaboration of culture broths. Waste Manag. 2019, 87, 472-484. [CrossRef] [PubMed]

41. Feng, X.-Q.; Li, Y.-Y.; Ma, C.-L.; Xia, Y.; He, Y.-C. Improved conversion of bamboo shoot shells to furfuryl alcohol and furfurylamine by a sequential catalysis with sulfonated graphite and biocatalysts. RSC Adv. 2020, 10, 40365-40372. [CrossRef]

42. Gong, L.; Xu, Z.-Y.; Dong, J.-J.; Li, H.; Han, R.-Z.; Xu, G.-C.; Ni, Y. Composite coal fly ash solid acid catalyst in synergy with chloride for biphasic preparation of furfural from corn stover hydrolysate. Bioresour. Technol. 2019, 293, 122065. [CrossRef]

43. Mou, H.; Li, B.; Fardim, P. Pretreatment of corn stover with the modified hydrotropic method to enhance enzymatic hydrolysis. Energy Fuels 2014, 28, 4288-4293. [CrossRef]

44. Kuterasiński, Ł.; Rojek, W.; Gackowski, M.; Zimowska, M.; Jodłowski, P. Sonically modified hierarchical FAU-type zeolites as active catalysts for the production of furan from furfural. Ultrason. Sonochem. 2020, 60, 104785. [CrossRef] [PubMed]

45. Bizzi, C.A.; Santos, D.; Sieben, T.C.; Motta, G.V.; Mello, P.A.; Flores, E.M. Furfural production from lignocellulosic biomass by ultrasound-assisted acid hydrolysis. Ultrason. Sonochem. 2019, 51, 332-339. [CrossRef]

46. Lee, C.B.T.L.; Wu, T.Y. A review on solvent systems for furfural production from lignocellulosic biomass. Renew. Sustain. Energy Rev. 2021, 137, 110172. [CrossRef]

47. Wang, B.; Wu, J.; Yuan, Z.Y.; Li, N.; Xiang, S. Synthesis of MCM-22 zeolite by an ultrasonic-assisted aging procedure. Ultrason. Sonochem. 2008, 15, 334-338. [CrossRef]

48. Jiang, C.-X.; Di, J.-H.; Su, C.; Yang, S.-Y.; Ma, C.-L.; He, Y.-C. One-pot co-catalysis of corncob with dilute hydrochloric acid and tin-based solid acid for the enhancement of furfural production. Bioresour. Technol. 2018, 268, 315-322. [CrossRef]

49. Sharma, V.; Nargotra, P.; Sharma, S.; Bajaj, B.K. Efficacy and functional mechanisms of a novel combinatorial pretreatment approach based on deep eutectic solvent and ultrasonic waves for bioconversion of sugarcane bagasse. Renew. Energy 2021, 163, 1910-1922. [CrossRef]

50. He, Y.; Ding, Y.; Ma, C.; Di, J.; Jiang, C.; Li, A. One-pot conversion of biomass-derived xylose to furfuralcohol by a chemoenzymatic sequential acid-catalyzed dehydration and bioreduction. Green Chem. 2017, 19, 3844-3850. [CrossRef]

51. Yang, T.; Chen, D.; Li, W.; Zhang, H. Efficient conversion of corn stover to 5-hydroxymethylfurfural and furfural using a novel acidic resin catalyst in water-1, 4-dioxane system. Mol. Catal. 2021, 515, 111920. [CrossRef]

52. Li, W.-C.; Zhang, S.-J.; Xu, T.; Sun, M.-Q.; Zhu, J.-Q.; Zhong, C.; Li, B.-Z.; Yuan, Y.-J. Fractionation of corn stover by two-step pretreatment for production of ethanol, furfural, and lignin. Energy 2020, 195, 117076. [CrossRef] 